\author{
Марина Љ. СПАСОЈЕВИЋ ${ }^{*}$ \\ Институт за српски језик САНУ \\ Београд
}

Оригинални научни рад

Примљен: 22. 3. 2021.

Прихваћен: 28. 4. 2021.

\title{
ТЕОРИЈСКИ ПРИСТУПИ ГЛАГОЛСКОМ ВИДУ У СРПСКОЈ ГРАМАТИКОГРАФИЈИ
}

\begin{abstract}
У раду се анализира заступљеност теоријско-методолошких приступа и праваца у представљању категорије глаголског вида и класификације глагола по виду у српским граматикама. Указује се и на примену теоријско-методолошких приступа аспектолошкој проблематици у српској лингвистичкој средини који су остали без утицаја на граматичке описе вида, а углавном су примењивани у контрастивним и типолошким истраживањима српског са другим језицима.

Кључне речи: граматике, глаголски вид, акционалност, традиционални приступ, структурализам, теорија функционално-семантичких поља.
\end{abstract}

1. Више од два века српске граматике карактерише традиционални приступ у представљању језичких датости, тј. поделу граматике по областима које описују језичке јединице од најмање ка већим: фонетика (и фонологија), морфологија, творба речи, лексикологија, ${ }^{1}$ синтакса (уп. Ломпар 2016: 13). Имајући у виду уобичајену прескриптивну и дидактичку улогу граматичких приручника, дефиниције граматичких појмова и категорија, као и класификације, наводе се као аксиоми, осим у ретким академским граматикама, где се указује на различите приступе, док се теоријско-критичка разматрања срећу у монографијама и чланцима посвећеним одговарајућој проблематици.

1.1. Категорија глаголског вида и подела глагола по виду неизоставна је приликом описа глагола у граматикама словенских језика, као инхерентно обележје и особена, универзална категорија словенског глагола, иако се и

${ }^{*}$ marina.spasojevic@isj.sanu.ac.rs

${ }^{* *}$ Овај рад финансирало је Министарство просвете, науке и технолошког развоја Републике Србије према Уговору број 451-03-68/2020-14/200174, који је склопљен са Институтом за српски језик САНУ.

${ }^{1}$ Природно, као новија дисциплина која за предмет проучавања има реч, „хијерархијски” долази овде, док творба речи има статус и самосталне дисциплине и дела морфологије и дела лексикологије у различитим приступима (Драгићевић 2010: 26-27). 
у другим светским језицима може говорити о начинима изражавања вида. Наиме, категорија глаголског вида у српском језику, кроз класификацију на свршене и несвршене (те обично даље и њихове подгрупе - видске ликове), прилично је хомогено представљана у српским граматикама и приручницима академске и школске намене, за разлику, рецимо, од класификације глагола по значењу или роду, које су врло неконсеквентно обрађиване (Ломпар 2016: 297-300). Циљ овога рада јесте да се сагледа, с једне стране, теоријско-методолошка утемељеност граматичких описа глаголског вида и уплив нових теоријских сазнања из области аспектологије у српске граматике. С друге, настоји се указати и на разраду и примену нових теоријско-методолошких оквира, који претежно улазе са контрастивним и типолошким истраживањима српског и других словенских и несловенских језика у лингвистичку литературу на српском језику ${ }^{2}$ (уп. Пипер 2018: 15, 24), а који за сада остају без утицаја на граматичке описе глаголског вида и с њим повезаних категорија у српском језику. Пошто су у монографији Ломпар 2016 детаљно анализиране врсте речи, њихове класификације и категорије у 23 граматике, ${ }^{3}$ а у раду Спасојевић 2017 терминологија везана за глаголски вид, ${ }^{4}$ то се овде неће по-

\footnotetext{
${ }^{2}$ Овом приликом није могуће дати исцрпан попис свих студија, а нарочито чланака.

${ }^{3}$ Вук Стефановић Караџић, Писменица сербскога їезика, Виена: у печатны Г. Іоанна, 1814; Ђуро Даничић, Мала српска граматика, Беч: Штампарија јерменскога манастира, 1850; Vjekoslav Babukić, Ilirska slovnica, Zagreb: Nar. tiskarnica Dr ${ }^{\mathrm{a}}$ Ljudevita Gaja, 1854; Стојан Новаковић, Српска граматика, Београд: Државна штампарија, 1894; Mirko Divković, Oblici hrvatskoga jezika za srednje škole, Zagreb: Tisak dioničke tiskare ${ }^{5} 1893$; Josip Florschütc, Gramatika hrvatskoga jezika za ženski licej, preparandije $i$ više pučke škole, Zagreb: Kr. zemaljska tiskara u Zagrebu, ${ }^{3}$ 1916; Јанко Лукић, Граматика српскога језика, Београд: Књижара Геце Кона, ${ }^{2} 1923$; Љубомир Стојановић, Српска граматика, Београд: Штампарија Краљевине Србије, ${ }^{18} 1908$; Tomislav M. Maretić, Gramatika hrvatskoga ili srpskoga književnog jezika, Zagreb: Matica hrvatska, 1899/31963; Жив. Н. Стефановић, Граматика српскохрватског језика за средње и стручне школе, Београд: Књижарница Радомира Д. Ћуковића, ${ }^{4} 1932$; Александар Белић, Граматика српскохрватског језика, Београд: Књижарница Геце Кона, 1933; Стјепан Мусулин, Граматика српскохрватскога језика за први, други, трећи и четврти разред средњих и њима сличних школа, Загреб: Наклада југословенског професорског друштва, секције загребачке, ${ }^{2} 1936$; Ivan Brabec et al., Gramatika hrvatskoga ili srpskoga jezika, Zabreb: Školska knjiga, ${ }^{2} 1954$; Игрутин Стевовић, Функционална граматика српскохрватског језика, Сарајево: Свјетлост, 1958; Михаило Стевановић, Савремени српскохрватски језик. Граматички системи и књижевнојезичка норма I. Увод, фонетика, морфологија, Београд: Научна књига, ${ }^{2} 1970$; Stjepko Težak, Stjepan Babić, Pregled gramatike hrvatskog književnog jezika za osnovne i druge škole, Zagreb: Školska knjiga, ${ }^{3} 1970$; Pavica Mrazović, Zora Vukadinović, Gramatika srpskohrvatskog jezika za strance, Novi Sad: Izdavačka knjižarnica Zorana Stojanovića, 1990; Josip Baotić et al., Naš jezik, udžbenik srpskohrvatskog/hrvatskosrpskog jezika za drugi razred srednjeg usmjerenog obrazovanja, Sarajevo: Svjetlost, Zavod za udžbenike i nastavna sredstva, ${ }^{2} 1990$; Stjepan Babić et al., Povijesni prijegled, glasovi i oblici hrvatskoga književnog jezika, Zagreb: HAZU, 1991; Eugenija Barić et al., Hrvatska gramatika, Zagreb: Školska knjiga, 1995; Радоје Симић, Српска граматика за средње школе, Београд: МХ „Актуал”, 1996; Душка Кликовац, Граматика српског језика за основну школу, Београд: Креативни центар, 2010; Живојин Станојчић, Љубомир Поповић, Граматика српскога језика за гимназије и средње школе, Београд: Завод за уџбенике и наставна средства, ${ }^{15} 2014$.

${ }^{4}$ Од граматичких приручника, поред Писменице, разматрана је и Српска граматика уз Вуков Рјечник, Даничић, Маретић, Белићеве граматике, али и појединачне студије, обе књиге Стевановићевог Савременог српског језика, друго издање граматике Мразовић/Вукадиновић 2010, Синтакса Пипер и др. 2005 и Нормативна граматика Пипер/Клајн 2014, али и контрастивне студије.
} 
нављати анализа описа глаголског вида, већ ће се трагати за теоријском подлогом описа глаголског вида у њима.

1.2. Како је показала Весна Ломпар (2016), анализирајући обраду врста речи поређењем граматика од Вука до данас, углавном се наилази на мање терминолошке разлике на релацији домаћа : страна реч за свршене и несвршене глаголе, као и за експлицитно помињање саме категорије, ${ }^{5}$ затим на различите критеријуме за ову класификацију и дефинисање: трајање радње : тренутак, ограниченост : неограниченост, извршеност : у вршењу, целина или тренутак : радња у трајању, не/постојање границе итд.; затим неподударање подврста - видских ликова, тј. акционалних класа у даљој подели свршених и несвршених глагола обично према семантичком критеријуму. Даље, разуме се, разликују се примери илустрације од граматике до граматике (Ломпар 2016: 312-322; о терминологији у контексту аспектолошких приступа развијаних у славистици и англосаксонској литератури видети и Спасојевић 2017). ${ }^{6}$

2. Српске граматике 19. и 20. века, па и неке из новог миленијума, традиционално су конципиране. Традиционални приступ проистекао је из младограматичарског правца, који је био усредсређен на историју, попис и опис језичких факата. Он се у 20. веку надограђује структуралистичким схватањем. Када је у питању глаголски вид, у славистици се у структурализму (и његовим правцима) проучава као морфолошка бинарна категорија. За време Пражана и Јакобсона у центру аспектолошких изучавања били су однос чланова бинарне видске опозиције и маркираност њених чланова, док је у западњачкој лингвистици вид посматран као универзална језичка категорија ${ }^{7}$ са различитим облицима испољавања, затим долази до развајања глаголског вида као граматичке и акционалности као семантичке категорије глагола итд.

2.1. Младограматичарско учење представља темеље традиционалног граматичког приступа. У 19. веку, нарочито у славистици, вид је описиван као граматичка (углавном бинарна морфолошка, ређе синтаксичка) категорија, било да је реч о компаративно-историјском методу, било да је реч о класичним граматичким описима неког савременог језика. Иако младограматичари у представљању језика полазе од морфолошких датости у сагледавању вида и зато се о виду пише у одељку о врстама и облицима речи, тј. о морфологији, што у српским граматичким описима видимо, рецимо, код Вука (1814; 1818) и Даничића (1859), Миклошић у четвртом тому књиге Vergleichende Grammatik der slavischen Sprachen (1868-1875) (Миклошић 1926) вид об-

\footnotetext{
${ }^{5}$ Именовање глаголског вида као посебне глаголске категорије срећемо најпре код Белића (Ломпар 2016: 322; Спасојевић 2017: 233), док се у ранијим граматикама (Вук, Даничић, Маретић) говори о подели на свршене и несвршене (према трајању).

${ }^{6}$ Анализирајући категорију глаголског вида у хрватским граматикама до 20. века, Жељка Брлобаш (2007: 12-13) додаје, осим поменутих, још разлика која се могу јавити међу граматикама: постоји ли опис перфективизације и имперфективизације глагола; да ли је опис заснован на морфолошком, синтаксичком или творбеном нивоу; на који је начин глаголски вид повезан са глаголским временима, облицима, семантичким класама глагола и другим категоријама (глаголска основа, (не)бројивост, (не)одређеност итд.).

${ }^{7}$ Овакав став заступа и Александар Белић (2000) у својој општелингвистичкој синтези.
} 
рађује у делу о синтакси, што је применио и Маретић (1899/1963: 476-483, т. 479-484; уп. Брлобаш 2007: 254).

2.2. У граматикама традиционалног приступа, на основу семантичких критеријума, свршени и несвршени глаголи деле се даље на подгрупе, подвидове, видске ликове и сл., укрштајући граматичку и семантичку поделу. Иако је на самом почетку 20. века - 1908 - Сигурд Агрел разграничио граматичку поделу глагола по виду и семантичку поделу по начину вршења радње, што је даље прихватио и разрађивао Ервин Кошмидер 1934, на српску граматичку праксу то није имало утицаја. Највећи и најутицајнији српски лингвиста 20. века Александар Белић у приказима ових студија није позитивно оценио нова гледишта и наставио је да развија своје учење о виду и подели глагола (уп. детаљније Спасојевић 2016). Белић у својим универзитетским предавањима из синтаксе (1931: 217) практично установљава (са терминолошким варијацијама) класификацију глагола на а) несвршене (неограничене, имперфективне), са значењем трајним и учестаним и б) свршене (ограничене, перфективне) са почетним завршним или тренутним значењем, а та значења у својој општелингвистичкој синтези назива врстом или ликом глаголског вида (Белић 2000: 262-263). Дакле, 20. век, првенствено прву половину и прву деценију друге половине, обележило је учење Александра Белића, његова оригинална разрада теорије о језику, која пре свега почива на језичким фактима, реалности. ${ }^{8}$ У Београдској школи његови ученици су следили његове поставке настављајући на његовим темељима, а структурализам није прихваћен на начин на који је то било у Новосадској, ивићевској школи (Пипер 2018: 23). Белићев најистакнутији следбеник Михаило Стевановић у својој дескриптивној граматици академског типа глаголски вид представио је и у делу о морфологији у првој књизи, сажето (Стевановић 1986: 326-327), и у другој књизи о синтакси (Стевановић 1898: 527-545), опширније, са разгранатијим бројем видских ликова. Иако је дао критички преглед дотадашњих теоријских проматрања у славистици (Виноградов, Исаченко, Маслов и др.), класификација није модификована. Но, оно што у српској граматикографији важи за глаголски вид, односи се и на целину, и обрнуто, по оцени у синтетичком прегледу српске славистике П. Пипера: „Касније граматике српскохрватског, одн. српског језика објављене у другој половини XX века већином су постепено доносиле извесне искораке ка савременој граматичкој теорији, али углавном без веће промене наслеђених теоријских основа" (Пипер 2018: 23).

3. Прве деценије 21. века доносе промене у српску граматикографију, па и у представљању категорија глаголског вида. Како је Агрелово и Кошмидерово разграничење све више разрађивано и примењивано у славистици (Исаченко, Маслов и др.), а своју је потпуну разраду достигло у теорији функционално-семантичких поља, то је оно ушло и у српске граматике.

\footnotetext{
8 За наше питање особена је функционална граматика Игрутина Стевовића (1958), која представља методолошку новину стављајућу у фокус синтаксичке функције морфолошких облика, чиме је развијала Белићеву идеју о односу значења, облика и функције граматичких јединица. У њој, наиме, нема обраде глаголског вида, што потврђује да вид није обличка, флективна категорија већ граматичка.
} 
3.1. Друго издање Граматике српског језика за странще Павице Мразовић и Зоре Вукадиновић (2009: 77-80), за разлику од првог, из 1990. са обрадом вида и класификације глагола по традиционалном приступу, доноси разграничење, више од једног века присутно у германској лингвистичкој средини и славистици, на акционалност и на аспект (глаголски вид) (80-92). Поред опозиције перфективност : имперфективност, у оквиру имперфективности указује се на уобичајеност (хабитуалност) : трајност, у оквиру које се разликује непрогресивност : прогресивност, у чему се види ослањање на Комријево учење. Иначе, оба издања, будући да су потекла из пера германиста, представљају значајну новину у српској граматикографији јер су писана из угла депенденцијалне или граматике зависности, па је на раздвојено представљање аспекта и акционалности утицало и германско лингвистичко наслеђе.

3.2. За развој аспектолошких проучавања у славистици од посебног значаја био је функционално-семантички приступ, који се развија од 60-их година 20. века. За разлику од традиционалног приступа, који иде од форме ка значењу, функционални подразумева кретање од семантике ка њеном формалном испољавању, што се заправо не искључује. У центру овог приступа налази се појам функционално-семантичког поља. Своју примену ова теорија у аспектологији нашла је разрадом А. В. Бондарка. Он је заслужан за развој лењинградске/санктпетербуршке/петроградске аспектолошке школе, чији је оснивач Маслов (Војводић 2001а: 47; уп. и Војводић 2002). ${ }^{9}$

3.2.1. У књизи Синтакса савременога српског језика. Проста реченица (Пипер и др. 2005) у великој мери теоријско-методолошку окосницу чини функционално-семантички приступ, али и семантички приступ који су у пољску лингвистику увели С. Каролак, 3. Тополињска и М. Гроховски својом тротомном граматиком 1994, те теорија семантичких локализација Предрага Пипера. Глаголски вид је обрађен приликом сагледавања односа темпоралности и аспектуалности, као део „Темпоралности” у оквиру категоријалног комплекса локализације, као семантичке категорије у простој реченици, што другим речима представља синтаксичку семантику. Категорија акционалности се не помиње, већ се говори о подвидским значењима, која су лексикализована, као инхоативност, терминативност, или временска значења у систему глаголских облика (Пипер и др. 2005: 780-783). Овим делом се уводи у српске граматике појам аспектуалност као исказивање видских и лексичко-ситуационих значења глагола на било ком језичком нивоу и свим језичким средствима.

3.2.2. Пажње је вредан и коауторски приручник о граматичким структурама и функцијама у јужнословенским језицима В. Малџијеве (бугарски), 3. Тополињске (македонски), М. Ђукановић (словеначки) и П. Пипера (словеначка синтакса и српски). Концепцијску основу чини приручник 3. Тополињске о македонском језику, који је такође заснован на пољској тротомној

\footnotetext{
${ }^{9}$ Поставке ове теорије нашле су своју примену у радовима Дојчила Војводића и граматичким описима Предрага Пипера.
} 
граматици. У делу о синтакси српског језика П. Пипер под тачком „Семантички и прагматички садржаји предикатског израза”, под насловом „Аспектуалност" обрађена је граматикализована морфолошка категорија глаголског вида (Пипер 2009: 497-499). У овом поглављу уочава се заступљеност функционално-семантичког приступа, као теорије локализације. У овом приручнику се одваја граматичка категорија вида од акционалности.

3.3. Нормативна граматика српског језика Предрага Пипера и Ивана Клајна има концепцију, устројство традиционалних граматика, али је видљива и примена новијих приступа у обради појединих питања, као и укључивање резултата новијих србистичких истраживања $(2013,2014)$. Глаголски вид се обрађује у оквиру морфологије (Пипер/Клајн 2014: 175-180), али се истиче да се значења која се изражавају „облицима свршеног и несвршеног вида" могу изражавати другим лексичким и синтаксичким средствима, што је у складу са теоријом функционално-семантичких поља. Категорија акционалности се посматра засебно и одређује се као лексичко-граматичка, а посебна пажња се посвећује видском парњаштву и средствима творења једног вида од другог.

4. Разликовање вида као граматичке категорије и начина радње - акционалности као семантичке у монографским студијама о српском језику среће се још пре средине 20. века. Најпре је монографија о глаголском виду у српскохрватском Ружић (1943), објављена у Америци. Критеријум за разликовање свршености и несвршености је трајање/завршеност и не/постојање границе, а - следећи Агрела и Кошмидера - сматра да сваки глагол има вид, као граматикализовану семантичку разлику трајања (којих има две), и акционалност, као лексикализовану која се изражава морфолошким (творбеним) средствима, а тих типова има много. Но, његова подела на акционалне класе нема јасне критеријуме. Ова је књига, претпостављамо, пре свега због времена у коме се појавала и околности које су је пратиле, остала без одјека у србистици. Међутим, студија Аспектна значења Ђуре Грубора (1953) била је запажена у своме времену, али није била позитивно оцењена у рецензији Александра Белића (1955-1956), као ни у још обимнијој и детаљнијој рецензији Белићевог ученика Јована Вуковића (1956) који је његово учење развијао у новом центру србистике - Сарајеву. По своме схватању перфективности и имперфективности Грубор је претеча западних аспектолога Комрија и др., јер гледа на њих као на целину и структуру. Своје место Груборова студија налази тек у библиографији новијих истраживања, првенствено контрастивних (уп. нпр. Новаков 2005 итд.).

5. С обзиром на чињеницу да се у несловенским језицима вид не манифестује као обавезна граматичка бинарна морфолошка категорија, већ се изражава глаголским облицима (као у француском), перифрастично (у шпанском, енглеском) и сл., у германској, англосаксонској и романској лингвистици развијали су се другачији погледи на вид и његово испољавање. Преко компаративних и типолошких студија са несловенским језицима, српска лингвистика упозната је и са аспектолошким теоријама развијаним на западу. 
5.1. Веома важну улогу у аспектологији при крају прве деценије друге половине 20. века имала је студија Зена Вендлера „Глаголи и време / Verbs and Times" (Вендлер 1957), у којој он, на основу грађе из енглеског језика, даје својеврсну семантичко-видску типологију глагола. Он је глаголе поделио у четири аспектуалне класе: глаголи стања (states) и три врсте догађаја: активности (actions), остварења (accomplishments, трајно-свршени догађаји) и достигнућа (achievements, тренутно-свршени догађаји). У изучавању српских глагола примењена је у студијама Кохран 1977; 1978; Новаков 2005; Станојевић/Ашић 2008 (у комбинацији са другим приступима).

5.2. Карлота Смит у својој студији The Parameter of Aspect (1991) веома комплексно прилази аспекту као универзалној језичкој категорији, уважавајући дотада развијане структуралистичке, генеративне и когнитивне теорије у својој типолошкој студији на примеру енглеског, француског, руског, мандаринског кинеског и навахо језика. Она је заговорник теорије двокомпонентног аспекта (two-component theory, Смит 1997: 14). Сличност аспекатских система различитих језика образлаже чињеницом да се аспекатски системи базирају на истим или сличним концептима (Смит 1991: 13), а разлике се испољавају језичким средствима исказивања. Смит истиче да се аспект састоји из две компоненте - вида (viewpoint aspect) и ситуационих типова (situation type). Теорија двокомпонентног аспекта примењена је у србистици у контрастивним студијама, нпр. Јовановић (2020).

5.3. Генеративна лингвистика Ноама Чомског, која истиче универзалност категорије вида у дубинској структури и њено различито испољавање у површинској, које не мора нужно бити везано за глагол, веома је заступљена у германској и англосаксонској лингвистици (Веркил, Даути, Дал, Биник, Смит, Крифка итд.). Преко помињаних контрастивних истраживања П. Новакова и, на другој страни, В. Станојевић и Т. Ашић и овај је правац био примењиван у тумачењу српских видско-временских и акционалних датости у саодносу са енглеским односно француским. Рецимо, Новаков полази од Вендлерове семантичке класификације глагола, јер сматра да она пружа добру основу за проучавање семантичких типова глагола, док за адекватно представљање граматичких и лексичких компоненти види решење у генеративном моделу „управљања и везивања” Ноама Чомског (Новаков 1998: 137). Такође је и коауторска студија уџбеничког типа Semantika i pragmatika glagolskih vremena u francuskom jeziku (Станојевић/Ашић 2008) заснована на више аспектолошких теорија: теорији генеративне, формалне семантике (Вендлер, Џекендоф, Вет) и теорији оптималитета.

5.4. У оквиру когнитивне лингвистике развило се више методолошких праваца, као што су теорија прототипа, примитива, концептуална анализа, теорија појмовних метафора, теорија менталних простора итд., а у оквиру њих је посвећивана пажња и питањима аспектологије (као што смо видели, комбинује се и са другим приступима). Проучавању аспекта у словенским језицима помоћу теорије појмовних метафора допринос је дала Л. Јанда. Категорија времена разуме се помоћу универзалне метафоре вРЕмЕ JE ПРОстоР. Аспект се даље концептуализује помоћу метафора СИТУАЦИЈЕ СУ МАТЕРИЈАЛ- 
НИ ЕНТИТЕТИ, а члаНови видске оПозиције метафорама ПЕРФЕКТИвНО ЈЕ КОМПАКТАН ПРЕДМЕТ : ИМПЕРФЕКТИВНО ЈЕ ФЛУИДНА МАТЕРИЈА. У сВојОј сТУДИјИ Драгана Вељковић Станковић (2013) категорију вида и чланове опозиције представила је у оквиру приступа појмовне метафоре, а теорија менталних простора примењује се у докторској тези Вање Миљковића о глаголској префиксацији (која је у изради).

6. Као што је представљено, србисти су директно или индиректно упознати са различитим приступима у поимању вида. Они налазе примену у студијама, али, како граматика тежи да представи стабилност, константе у језику и како у свим сегментима мора бити теоријско-методолошки доследна (ово није оправдање за опаску да се граматике само преписују), нови теоријско-методолошки приступи спорије налазе пут до граматичких описа. Друго, не узимају се у обзир све студије, Треће, нека академска граматика мора бити општеприхваћена, односно њене дефиниције и класификације узете као релевантене у широј лингвистичкој заједници да би се нешто што је устаљено и уврежено мењало у школским граматикама. Традиционални приступ је опстао, а у њега су у мањој или већој мери уткивани резултати новијих теоријско-методолошких приступа.

\section{ЛИТЕРАТУРА}

Белић 1931: А. Белић, Синтакса српскохрватског језика, литографисано издање [универзитетска предавања], Београд, 1-158.

Белић 1933: А. Белић, Граматика српскохрватског језика за трећи разред средюих и стручних школа, Београд: Издавачка књижарница Геца Кон.

Белић 1934: А. Белић, Koschmieder Erwin, Nauka o aspektach czasownika polskiego w zarysie. Próba syntezy. Wilno. 1934. XVI + 240, $8^{0}$. Изашло у колекцији Rozprawy i materjałi wydziały I Towarzystwa przyjaciół nauk w Wilnie. Tom v, zeszyt 2, Јужнословенски филолог, XIII, 218-227.

Белић 1955-1956: А. Белић, Ђуро Грубор, Аспектна значења, $\operatorname{Rad} 293$, 5-234, Јужнословенски филолог, ХХІ/1-4, 291-303.

Белић 2000: А. Белић, Општа лингвистика. О језичкој природи и језичком развитку, Изабрана дела Александра Белића, том 1, Београд: Завод за уџбенике и наставна средства.

Брлобаш 2007: Ž. Brlobaš, Glagolski vid u hrvatskim gramatikama do 20. stoljeća, Zagreb: Institut za hrvatski jezik i jezikoslovlje.

Вељковић Станковић 2013: Д. Вељковић Станковић, Могућности примене когнитивног приступа у настави српског језика (на примеру обраде граматичке категорије глаголског вида), Научни састанак слависта у Вукове дане, 42/3, 85-113.

Вендлер 1957: Z. Vendler, Verbs and Times, The Philosophical Review, 66, 143-160.

Војводић 2001: Д. Војводић, О функционалним основама савремене аспектологије, Славистика, V, 44-55. 
Војводић 2002: Д. Војводић, Аспектуално-темпорални односи у свјетлу граматике функционално-семантичких поља и категоријалних ситуација (А. В. Бондарко, Основы функциональной грамматики: Языковая интерпретация идеи времени, Санкт-Петербург, Издательство Санкт-Петербурского университета, 1999, 260), Зборник Матиие српске за славистику, 61, 192-199.

Вук 1814: Писменииа сербскога іезика, по говору простога народа написана Вуком Стефановићем Сербиіанцем, у Виенни: У печатньи Г. Іоанна Шнирера.

Вук 1818: Српски рјечник истолкован њемачким и латинским ријечима, скупио га и на свијет издао Вук Стефановић, у Бечу: Штампарија јерменског манастира. http://eng.digital.nb.rs/document/S-II-0458 (15. 4. 2011).

Вуковић 1956: J. Vuković, Đuro Grubor, Aspektna značenja (Rad JAZU, knj. 193, str. 5-231, knj. 195, str. 81-284), Pitanja savremenog književnog jezika, III/1-2, 177-195.

Грубор 1953: Đ. Grubor, Aspektna značenja, Rad JAZU, knj. 193, 5-231; knj. 195, 81-284, Zagreb: Jugoslavenska akademija znanosti i umjetnosti.

Даничић 1850: Ђ. Даничић, Мала српска граматика, Беч: Штампарија јерменског манастира.

Драгићевић 22010: Р. Драгићевић, Лексикологија српског језика, Београд: Завод за уџбенике.

Јовановић 2020: В. Јовановић, Преводна парадигма српског перфекта у франиуском језику, Крагујевац: Филолошко-уметнички факултет.

Комри 1976: B. Comrie, Aspect, An introduction to the study of verbal aspect and related problems, Cambridge: Cambridge University press.

Кохран 1977: N. J. Cochrane, Verbal Aspect and the Semantic Classification of Verbs in Serbo-Croatian, $\mathrm{PhD}$ dissertation, University of Texas at Austin.

Кохран 1978: N. Cochrane, Some Problems in the representation of Verbal Aspect Pairs in the Lexicon, $u$ : Rudolf Filipović (ur.), Kontrastivna analiza engleskog i hrvatskog ili srpskog jezika, II, Zagreb: Zavod za lingvistiku Filozofskog fakulteta Sveučilišta u Zagrebu, 101-139.

Ломпар 2016: В. Ломпар, Врсте речи и граматичка пракса (од Вука до данас), Београд: Друштво за српски језик и књижевност Србије.

Маретић 1963: T. Maretić, Gramatika i stilistika hrvatskoga ili srpskoga književnog jezika, Zagreb: Matica hrvatska.

Миклошич 1926: F. Miklosich, Vergleichende Grammatik der slavichen Sprachen, IV: Syntahx, Heidelberg, 274-340.

Мразовић/Вукадиновић ${ }^{1}$ 1990: P. Mrazović, Z. Vukadinović, Gramatika srpskohrvatskog jezika za strance, Sremski Karlovci: Izdavačka knjižarnica Zorana Stojanovića - Novi Sad: Dobra vest.

Мразовић/Вукадиновић 22009: P. Mrazović [u saradnji sa Z. Vukadinović], Gramatika srpskohrvatskog jezika za strance, Sremski Karlovci: Izdavačka knjižarnica Zorana Stojanovića.

Новаков 1998: P. Novakov, Jedna reinterpretacija kategorije glagolskog vida, Зборник Матиие српске за филологију и лингвистику, XLI/2, 133-139. 
Новаков 2005: P. Novakov, Glagolski vid i tip glagolske situacije u engleskom $i$ srpskom jeziku, Novi Sad: Futura publikacije.

Пипер и др. 2005: П. Пипер, И. Антонић, В. Ружић, С. Танасић, љ. Поповић, Б. Тошовић, Синтакса савременог српског језика: проста реченица, у ред. М. Ивић, Београд: Институт за српски језик САНУ, Београдска књига - Нови Сад: Матица српска.

Пипер 2009: П. Пипер, Српски језик, у: В. Малџијева, 3. Тополињска, М. Ђукановић, П. Пипер, Јужнословенски језици. Граматичке структуре и функиије, ред. П. Пипер, Београд: Београдска књига, 381-536.

Пипер/Клајн 22014: П. Пипер, И. Клајн, Нормативна граматика српског језика, друго, измењено и допуње издање, Нови Сад: Матица српска.

Пипер 2018: П. Пипер, О српској лингвистичкој славистици друге половине XX века, y: Р. Драгићевић, В. Брборић (ур.), Српска славистика (колективна монографија). Том І. Језик, Београд: Савез славистичких друштава Србије, 7-36.

Ружић 1943: R. H. Ružić, The Aspects of Verb in Serbo-Croatian, Berkeley - Los Angeles: University of California Press.

Смит 1991: C. Smith, The Parameter of Aspect, Dordrecht-Boston-London: Kluwer Academic Publishers.

Спасојевић 2016: М. Спасојевић, Белићево схватање глаголског вида и његов утицај на развој аспектолошких погледа у србистици, Научни састанак слависта у Вукове дане, 45/1, 73-84.

Спасојевић 2017: М. Спасојевић, Појмовно-терминолошки апарат при проучавању глаголског вида и сродних појава у србистици у светлу аспектолошких приступа, $y$ : П. Пипер, В. Јовановић (ур.), Словенска терминологија данас, Београд: Српска академија наука и уметности, 227-241.

Станојевић/Ашић 22008: V. Stanojević, T. Ašić, Semantika i pragmatika glagolskih vremena u francuskom jeziku, Kragujevac: Filološko-umetnički fakultet.

Станојчић/Поповић ${ }^{152014}$ : Ж. Станојчић, Љ. Поповић, Граматика српскога језика, Београд: Завод за уџбенике и наставна средства.

Стевановић 51986: М. Стевановић, Савремени српскохрватски језик, I: Граматички системи и књижевнојезичка норма, Београд: Научна књига.

Стевановић ${ }^{4}$ 1989: М. Стевановић, Савремени српскохрватски језик, II: Синтакса, Београд: Научна књига. 


\section{М. Л. Спасоевич}

\section{ТЕОРЕТИЧЕСКИЕ ПОДХОДЫ К ГЛАГОЛЬНОМУ ВИДУ В СЕРБСКОЙ ГРАММАТИКОГРАФИИ}

\section{Резюме}

В работе указывается, что в сербских грамматиках в XIX и XX веках использовался традиционный подход. Новые познания в течение этих двух веков внедрялись медленно. Начало XX века внесло изменения в классификацию глагольного вида в соответствии, прежде всего, с теорией функционально-семантических полей, но и с теорией семантических локализаций. Указывается и на применение теоретическо-методологических подходов к аспектологическим проблемным вопросам в сербской лингвистической среде, оставшихся без влияния на грамматические описания вида. Они в основном применялись в сопоставительных и типологических исследованиях сербского и других языков, в том числе аспектуальные классы Вендлера, теория двухкомпонентного аспекта и т. д.

Ключевые слова: грамматики, глагольный вид, акциональность, традиционный подход, структурализм, теория функционально-семантических полей. 